\title{
Immunostimulant Activity of Gracilaria sp. and Padina sp. on Immune System of Vannamei Shrimp (Litopenaeus vannamei) Against Vibrio harveyi
}

\author{
Yuni Kilawati ${ }^{1 *}$ and Raden Adharyan Islamy ${ }^{2}$ \\ ${ }^{1}$ Water Resources Management, Faculty Of Fisheries And Marine Science, Brawijaya University, Jl. \\ Veteran, Ketawanggede, Kec. Lowokwaru, Malang, East Java 65145 Indonesia \\ ${ }^{2}$ Department Of Aquaculture, Faculty Of Fisheries And Marine Science, Brawijaya University, $\mathrm{Jl}$. \\ Veteran, Ketawanggede, Kec. Lowokwaru, Malang, East Java 65145 Indonesia
}

*Correspondence :

yuniqla3@gmail.com

Received : 2020-11-03

Accepted : 2021-03-25

Keywords :

Immunostimulant, Gracilaria sp., Hemocyte, Litopenaeus vannamei, Padina sp.

\begin{abstract}
The pathogenic bacterial infection is one of the problems in the cultivation of vannamei shrimp (Litopenaeus vannamei), causing a high mortality rate of cultured shrimp. The use of antibiotics or chemicals with inappropriate concentrations can harm the aquatic environment, cause resistance, and endanger consumer health because the residues from the chemicals used will periodically accumulate in the body of shrimp. One way to control and prevent shrimp disease is to increase the shrimp immune system by using immunostimulants from seaweed. This study aims to analyze the immunostimulant activity of seaweed extract (Gracilaria sp. and Padina sp.) against vannamei shrimp (L. vannamei) infected with Vibrio harveyi by observing the nonspecific immune system based on its hematological features, namely by counting the number of hemocytes and phagocytic activity. The research was conducted at the Hatchery Unit, Brackish Water Cultivation Development Center (BPAP) Situbondo, East Java. Seaweed sample Gracilaria sp. and Padina sp. purchased from seaweed farmers in Jepara, Central Java. The result of this study shows that supplementation of Gracilaria sp. and Padina sp. at a dose of $10 \mathrm{~g} / \mathrm{kg}$ of feed can increase the total number of hemocytes and phagocytosis activity of $L$. vannamei shrimp. The best treatment is Gracilaria sp.
\end{abstract}

\section{INTRODUCTION}

The pathogenic bacterial infection is one of the problems in the cultivation of vannamei shrimp (Litopenaeus vannamei), causing a high mortality rate of cultured shrimp. Pathogenic bacteria that commonly attack in shrimp culture are Vibrio bacteria (Nitimulyo et al., 2005). Vibrio harveyi is the most popular bacteria that causes vibriosis disease that worries shrimp farmers because it can cause shrimp mortality up to $80 \%$ within a few days (Israngkura and Sae-Hae, 2002). This disease can also cause mass mortality in both hatchery and the enlargement of vannamei shrimp because of its virulent nature (Soonthornchai et al., 2010). The clinical symptoms of shrimp infected with vibriosis show a reddish black color, and several external organs appear red, especially on the gills and limbs (Saptiani et al., 2012). 
Shrimp farmers have done treatment with antibiotics and other drugs without a veterinary prescription (Lim et al., 2020). However, the use of antibiotics or chemicals with inappropriate concentrations can harm the aquatic environment, cause resistance, and endanger consumer health because the residues from the chemicals used will periodically accumulate in the body of shrimp (Defoirdt et al., 2007; Kraemer et al., 2019). One way to control and prevent shrimp disease is to increase the shrimp immune system by using immunostimulants, vitamins, and hormones (Johnny et al., 2005; Mahasri et al., 2018).

Seaweed is a multicellular alga containing immunologically active substances. Several studies have shown that seaweed has prospects that are still open for development in the field of disease control. Seaweed extract can increase macrophage chemotaxis activity, stimulates oxygen radical secretion activity, and phagocytosis in peritoneal and splenic murine macrophages (Hou and Chen, 2005). Secondary metabolites such as phenolic compounds from some seaweed can increase shrimp's immunostimulatory activity (Hou and Chen, 2005; Selvin et al., 2004; Klongklaew et al., 2020).

\section{METHODOLOGY}

\section{Place and Time}

The research was conducted in July 2020 at the Hatchery Unit, Brackish Water Cultivation Development Center (BPAP) Situbondo, East Java. Seaweed sample Gracilaria sp. and Padina sp. purchased from seaweed farmers in Jepara, Central Java.

\section{Research Design}

This study aims to analyze the immunostimulant activity of seaweed extract (Gracilaria sp. And Padina sp.) against vannamei shrimp (L. vannamei) infected with Vibrio harveyi by observing the nonspecific immune system based on its hematological features, namely by counting the number of hemocytes and phagocytic activity.

\section{Work Procedure \\ Seaweed Extract Preparation}

Seaweed samples were cleaned then dried by shade drying (avoid direct sunlight). The L. vannamei shrimp were obtained from the cultivation of BPAPSitubondo with a weight of \pm 15 grams.

The dried seaweed is powdered according to published articles (Kilawati and Islamy, 2019), i.e., the seaweed is cleaned using freshwater then shadedrying for four days. Dried seaweed then ground until seaweed powder obtained. Total of $500 \mathrm{~g}$ seaweed powder put into a jar, then macerated using methanol 1: 3 $(\mathrm{w} / \mathrm{v})$ for $3 \times 24$ hours at room temperature, in three times replication. The maceration solution is then filtered using filter paper (Whatman no. 41), then filtrate and residue obtained. The filtrate then evaporated using a rotary evaporator vacuum at $40^{\circ} \mathrm{C}$ until a concentrated extract was obtained and calculated the percentage of yield.

A total of 500 grams of seaweed powder is boiled with 2 liters of distilled water for 2 hours, then filtered. The dregs are boiled again, then filtered, and the filtrate is combined with the first extraction results. The extracted solution is evaporated using a rotary evaporator until dry.

\section{Shrimp Feed Preparation}

The Commercial shrimp feed (composition: 40\% crude protein, 11\% water, and 3\% fiber) (Ridlo and Pramesti, 2009) is crushed and then added with seaweed extract as much as $10 \mathrm{~g} / \mathrm{kg}$ of feed, mixed until homogeneous and done pellets used for the test. The shrimp test was acclimatized in a tub equipped with an aeration system and water circulation for 15 days as well as commercial pellet feeding ad libitum (until full), each aquarium containing 15 shrimp (Rodríguez et al., 2004). Feeding during 
the treatment was carried out 4 times a day, that is, in the morning (05.30), afternoon (11.30), evening (17.30), and evening (23.00) as much as $5 \%$ of the bodyweight of the shrimp based on the published method (Esteban et al., 2001; Rodríguez et al., 2004; Haliman, 2005).

\section{Bacterial Preparation}

The isolate of $V$. harveyi was purchased from Jepara Brackishwater Aquaculture Center. Preparation procedure according to the published article (Islamy, 2019). These bacteria were kept in Trypticase Soy Agar (TSA) media at $4^{\circ} \mathrm{C}$ and sub-cultured Trypticase Soy Broth (TSB) overnight at room temperature before use. There is no added salt in TSB during the research.

\section{Data Analysis}

Shrimp hemolymph samples were collected at the base of the pleopod in the abdominal segment, near the genital opening, using a $1 \mathrm{~mL}$ syringe moistened with an anticoagulant solution (EDTA $10 \%)$. Hemolymph was taken at intervals of 4 days for 12 days, then placed in a sterile microtube and preserved in a cool box. According to a published procedure, determine total hemocyte count (THC) using a hemocytometer (Campa-Córdova et al., 2002).
Total hemocyte

$=\frac{\text { cell counted }}{\text { volume counted }} \times$ dilution $\times 10^{6}$

Determination of Phagocytic activity according to the published method (Isnansetyo, 2007). The $V$. harveyi bacterial cells were mixed with formalin solution until all the suspension precipitates were immersed for 24 hours, centrifuged at $1000 \mathrm{rpm}$ for 3 minutes, and the filtrate was separated. A total of $250 \mu \mathrm{L}$ of hemocytes were mixed with 500 $\mu \mathrm{L}$ of the killed bacterial suspension, then incubated at room temperature for 60 minutes. Phagocytic activity was observed using a 1000 magnification microscope.

$$
\begin{aligned}
& \text { Phagocytic activity (\%) } \\
& =\frac{\text { Number of active phagocytic cells }}{\text { The observed number of phagocytic cells }} \times 100 \%
\end{aligned}
$$

\section{RESULTS AND DISCUSSION}

The immune response of $L$. vannamei shrimp against $V$. harveyi bacterial infection and the effect of immunostimulants application from seaweed can be indicated through the hematological features, namely the total number of hemocytes and phagocytic activity. Hemocytes are a form of cellular defense for the body. Hemocytes can kill infectious agents through the synthesis and exocytosis of microbicidal protein bioactive molecules (Smith et al., 2003).

Table 1. The effect of seaweed extract administration on Total Hemocyte Count (THC) of shrimp L. vannamei.

\begin{tabular}{lcccc}
\hline \multicolumn{1}{c}{ Treatment } & \multicolumn{4}{c}{ Total Hemocyte $\left(\times 10^{7}\right.$ cell/L) } \\
& day 0 & day 4 & day 8 & day 12 \\
\hline without immunostimulant & $0.323 \pm 0.068$ & $0.462 \pm 0.151$ & $0.398 \pm 0.100$ & $0.547 \pm 0.063$ \\
Gracilaria sp. & $0.541 \pm 0.160$ & $0.858 \pm 0.321$ & $1.127 \pm 0.260$ & $0.311 \pm 0.038$ \\
Padina sp. & $0.561 \pm 0.055$ & $0.756 \pm 0.203$ & $1.091 \pm 0.533$ & $0.352 \pm 0.100$ \\
\hline
\end{tabular}

Table 1. Phagocytic activity during the study.

\begin{tabular}{lcccc}
\hline \multicolumn{1}{c}{ Treatment } & day 0 & Phagocytic Activity (\%) \\
& day 4 & day 8 & day 12 \\
\hline without immunostimulant & $78.601 \pm 2.10$ & $81.216 \pm 1.69$ & $90.216 \pm 2.16$ & $95.346 \pm 1.14$ \\
Gracilaria sp. & $87.008 \pm 3.29$ & $101.447 \pm 46.66$ & $85.862 \pm 3.64$ & $53.258 \pm 1.89$ \\
Padina sp. & $86.654 \pm 3.30$ & $101.308 \pm 60.38$ & $89.256 \pm 129$ & $63.474 \pm 2.14$ \\
\hline
\end{tabular}

The results showed that the number of hemocytes and phagocytic activity varied, depending on the treatment time length. The administration of seaweed 
extract tends to increase the total number of hemocytes and phagocytic activity up to day 8. The increase in the number of hemocytes is a measure of a substance's ability to stimulate the shrimp immune system. The increased phagocytic activity was characterized by a significant increase in the percentage of phagocytic cells (Pope et al., 2011). However, on day 12 the total number of hemocytes and phagocytosis activity decreased faster than the control. On the 8th day, Gracilaria sp. shows the highest value compared to Padina sp. and control. In contrast, on the $12^{\text {th }}$ day, the extract of Sargassum sp. and Padina sp. reduced hemocyte and phagocytic activity compared to controls.

Shrimp hematocytes play an important role in immune response, including through recognition, phagocytosis, melanization, cytotoxicity and communication between cells (Johansson et al., 2000). It shows that the administration of seaweed extract can increase the total hemocytes and phagocytosis activity of $L$. vannamei shrimp. We assume that the decrease in the number of hemocytes and phagocytosis activity on day 12 is due to the shrimp's immune system having gradually completed its fight against $V$. harveyi bacterial infection. The administration of certain plant extracts containing active compounds from the alkaloid class will increase the resistance of the fish body so that the hematological value of the fish returns to the normal range (Nurjannah et al., 2013).

Phagocytosis activity is one of the most important ways of controlling and destroying foreign particles. Through phagocytosis, the immune process is divided into several processes, namely: chemotaxis, recognition, and internalization (Bachère et al., 1995). Hemocytes perform inflammatory-type reactions such as phagocytosis, hemocyte clumping, production of oxygen-reactive metabolites, and microbicidal proteins release (Smith et al. 2003).

\section{CONCLUSION}

Supplementation of Gracilaria sp. and Padina sp. at a dose of $10 \mathrm{~g} / \mathrm{kg}$ of feed can increase the total number of hemocytes and phagocytosis activity of $L$. vannamei shrimp. That treatment was increasing simultaneously depending on the dose and time. The best treatment is Gracilaria sp.

\section{ACKNOWLEDGMENT}

The authors would like to express great gratitude to everyone who supported this study.

\section{REFERENCES}

Bachère, E., E. Mialhe, E., Noel, D., Boulo, V., Morvan, A. and Rodriguez, J., 1995. Knowledge and research prospects in marine mollusc and crustacean immunology. Aquaculture, 132(1-2), pp.17-32. htt ps://doi.org/10.1016/0044-8486(9 4)00389-6

Campa-Córdova, A.I., HernándezSaavedra, N.Y., De Philippis, R. and Ascencio, F., 2002. Generation of superoxide anion and SOD activity in haemocytes and muscle of American white shrimp (Litopenaeus vannamei) as a response to $\beta$-glucan and sulphated polysaccharide. Fish \& shellfish immunology, 12(4), pp.353-366. https://doi.org/10.1006/fsim.2001. 0377

Defoirdt, T., Boon, N., Sorgeloos, P., Verstraete, W. and Bossier, P., 2007. Alternatives to antibiotics to control bacterial infections: luminescent vibriosis in aquaculture as an example. Trends in biotechnology, 25(10), pp.472-479. https://doi.org /10.1016/j.tibtech.2007.08.001

Esteban, M.A., Cuesta, A., Ortuno, J. and Meseguer, $\quad$ J., 2001. Immunomodulatory effects of dietary intake of chitin on gilthead seabream (Sparus aurata L.) innate immune system. Fish \& shellfish immunology, 11(4), pp.303-315. 
https://doi.org/10.1006/fsim.2000. 0315

Haliman, R.W., 2005. Udang Vannamei. Penebar Swadaya. Jakarta

Hou, W.Y. and Chen, J.C., 2005. The immunostimulatory effect of hotwater extract of Gracilaria tenuistipitata on the white shrimp Litopenaeus vannamei and its resistance against Vibrio alginolyticus. Fish \& Shellfish Immunology, 19(2), pp.127-138. https://doi.org/10.1016/j.fsi.2004. 11.009

Islamy, R.A., 2019. Antibacterial Activity of Cuttlefish Sepia sp.(Cephalopoda,) Ink Extract Against Aeromonas hydrophila. Majalah Obat Tradisional, 24(3), pp.184-188. https://doi.org/10.221 $46 /$ mot. 45315

Isnansetyo, A., 2007. Petunjuk Praktikum Hematologi Ikan (Evaluasi Pertahanan Non Spesifik Ikan), Pelatihan Hematologi Ikan, Laboratorium Hama dan Penyakit Ikan, Universitas Gadjah Mada, Yogyakarta.

Israngkura, A. and Sae-Hae, S., 2002. A review of the economic impacts of aquatic animal disease. FAO fisheries technical paper, pp.253-286.

Johansson, M.W., Keyser, P., Sritunyalucksana, K. and Söderhäll, K., 2000. Crustacean haemocytes and haematopoiesis. Aquaculture, 191(1-3), pp.45-52. https://doi.org /10.1016/S0044-8486(00)00418-X

Johnny, F., Roza, D., Mahardika, K., Zafran, Z. and Prijono, A., 2005. Penggunaan Immunostimulan Untuk Meningkatkan Kekebalan Nonspesifik Benih Ikan kerapu Lumpur, Epinephelus coiodes Terhadap infeksi Virus irido. Jurnal Penelitian Perikanan Indonesia, 11(5), pp.75-83. http://dx.doi.org/ 10.15578/jppi.11.5.2005.75-83

Kilawati, Y. and Islamy, R.A., 2019. The Antigenotoxic Activity of Brown Seaweed (Sargassum sp.) Extract Against Total Erythrocyte and
Micronuclei of Tilapia Oreochromis niloticus Exposed by Methomyl-Base Pesticide. The Journal of Experimental Life Science, 9(3), pp.205-210. http://dx.doi.org/10.2 1776/ub.jels.2019.009.03.11

Klongklaew, N., Praiboon, J., Tamtin, M. and Srisapoome, P., 2020. Antibacterial and Antiviral Activities of Local Thai Green Macroalgae Crude Extracts in Pacific White Shrimp (Litopenaeus vannamei). Marine Drugs, 18(3), p.140. https:// doi.org/10.3390/md18030140

Kraemer, S.A., Ramachandran, A. and Perron, G.G., 2019. Antibiotic pollution in the environment: from microbial ecology to public policy. Microorganisms, 7(6), p.180. https:/ /doi.org/10.3390/microorganisms7 060180

Lim, J. M., Duong, M. C., Hsu, L. Y., \& Lim, J.M., Duong, M.C., Hsu, L.Y. and Tam, C.C., 2020. Determinants influencing antibiotic use in Singapore's small-scale aquaculture sectors: A qualitative study. PloS one, 15(2), p.e0228701. https://doi. org/10.1371/journal.pone.0228701

Mahasri, G., Sari, P.D.W. and Prayogo, 2018. Immune response and parasitic infestation on Pacific white shrimp (Lithopenaeus vannamei) in immuno-probio circulation system (SI-PBR) in ponds. IOP Conference Series: Earth and Environmental Science, 137, 012024. https://doi.or $\mathrm{g} / 10.1088 / 1755-1315 / 137 / 1 / 0120$ 24

Nitimulyo, K.H., Isnansetyo, A., Triyanto, T., Istiqomah, I. and Murdjani, M., 2005. Isolasi, identifikasi dan karakterisasi vibrio spp. Patogen peislyebab vibriosis pada kerapu di balai budidaya air payau Situbondo. Jurnal Perikanan, 7(2), pp.80 - 94. https://doi.org/10.22146/jfs.9053

Nurjannah, R.D.D., Prayitno, S.B., Sarjito, S. and Lusiastuti, A.M., 2013. Pengaruh Ekstrak Daun Sirsak (Annona muricata) Terhadap Profil Darah Dan Kelulushidupan Ikan Mas 
(Cyprinus carpio) Yang Diinfeksi Bakteri Aeromonas hydrophila. Journal of Aquaculture Management and Technology, 2(4), pp.72-83. https://ejournal3.undip.ac.id/index .php/jamt/article/view/4808

Pope, E.C., Powell, A., Roberts, E.C., Shields, R.J., Wardle, R. and Rowley, A.F., 2011. Enhanced cellular immunity in shrimp (Litopenaeus vannamei) after 'vaccination'. Plos one, 6(6), p.e20960. https://doi.org/10.1371/ journal.pone.0020960

Ridlo, A. and Pramesti, R., 2009. Aplikasi Ekstrak Rumput Laut Sebagai Agen Imunostimulan Sistem Pertahanan Non Spesifik Pada Udang (Litopenaeus vannamei). ILMU KELAUTAN: Indonesian Journal of Marine Sciences, 14(3), pp.133-137. https://doi.org/10.14710/ik.ijms.1 4.3.133-137

Rodŕiguez, A., Cuesta, A., Esteban, M.A. and Meseguer, J., 2004. The effect of dietary administration of the fungus Mucor circinelloides on nonspecific immune responses of gilthead seabream. Fish \& shellfish immunology, 16(2), pp.241-249. https://doi.org/10.1016/S10504648(03)00082-2

Saptiani, G., Prayitno, S.B. and Anggoro, S., 2012. Antibacterial activity of Jeruju (Anacthus ilicifolius) extracts on the growth of Vibrio harveyi in vitro. Jurnal Veteriner, 13(3), pp.257-262. https://ojs.unud.ac.id/ index.php/jvet/article/view/6013

Selvin, J., Huxley, A.J. and Lipton, A.P., 2004. Immunomodulatory potential of marine secondary metabolites against bacterial diseases of shrimp. Aquaculture, 230(1-4), pp.241-248. https://doi.org/10.1016/S0044-84 86(03)00427-7

Smith, V.J., Brown, J.H. and Hauton, C., 2003. Immunostimulation in crustaceans: does it really protect against infection?. Fish \& Shellfish Immunology, 15(1), pp.71-90. https:
//doi.org/10.1016/S1050-4648(02 )00140-7

Soonthornchai, W., Rungrassamee, W., Karoonuthaisiri, N., Jarayabhand, P., Klinbunga, S., Söderhäll, K. and Jiravanichpaisal, $\quad$ P., 2010. Expression of immune-related genes in the digestive organ of shrimp, Penaeus monodon, after an oral infection by Vibrio harveyi. Developmental \& Comparative Immunology, 34(1), pp.19 - 28. https://doi.org/10.1016/j.dci.2009. 07.007 